\title{
Somatotype Role and Performance in Ultra Trail Runners*
}

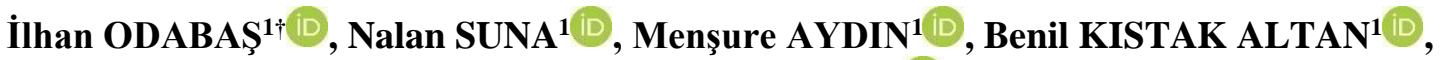 \\ Mustafa Arslan BAŞAR ${ }^{1}$ \\ ${ }^{1}$ Halic University, School of Physical Education and Sport, Istanbul.
}

Original Article

Received: 02.07.2021
Accepted: 20.11.2021
DOI:10.25307/jssr.961171

Online Publishing: 31.12.2021

\begin{abstract}
The aim of this study is to compare the somatotype of male running Ultra-trail race at different distances and to evaluate the race performance relationship. A total of 44 runners, average of age $45.64 \pm 9.16$ years; average of height $175.84 \pm 6.18 \mathrm{~cm}$; average of body weight $75.36 \pm 7.46 \mathrm{~kg}$, who ran distances of $13 \mathrm{~km}(\mathrm{n}=6), 30 \mathrm{~km}(\mathrm{n}=19), 66 \mathrm{~km}(\mathrm{n}=14)$ and $100 \mathrm{~km}(\mathrm{n}=$ 5 ), participated voluntarily in the study. Heath \& Carter method was used to determine the somatotypes of the runners. The running performance times were taken from the race results section on the organization's website. One-way ANOVA test was used to compare the running groups, and the Pearson correlation test was used for correlation analysis ( $\mathrm{p}<0.05)$. As a result, there was a significant difference in endomorph $(\mathrm{p}=0.000)$ and mesomorph $(\mathrm{p}=0.035)$ of the groups. Significant differences were observed between the endomorph of $13 \mathrm{~km}$ runners compared with $30 \mathrm{~km}(\mathrm{p}=0.003), 66 \mathrm{~km}(\mathrm{p}=0.002)$ and $100 \mathrm{~km}(\mathrm{p}$ $=0.005$ ) runners. It was found that those who run $13 \mathrm{~km}$ had more mass than those who run 30,60 and $100 \mathrm{~km}$, and as the distance increased, the endomorph and mesomorph values decreased, and the long-distance running athletes had a more linear physical structure. In Ultra Trail runs the somatotype differs according to the distance, and it can be said that the somatotype mesomorphic-ectomorph as the performance time and distance increases.
\end{abstract}

Keywords: Somatotype, Anthropometry, Ultra-trail Runners.

\section{Ultra-Trail Koşucularında Somatotip Rolü ve Performans}

\section{$\ddot{\mathbf{O} z}$}

Bu çalışmanın amacı Ultra-trail yarışlarına katılan erkek koşucularının somatotiplerini karşılaştırmak ve yarış performansı ile iliş̧kisini değerlendirmektir. Çalışmaya yaş ortalaması $45.64 \pm 9.16$ yıl; boy ortalamas $175.84 \pm 6.18 \mathrm{~cm}$; vücut ağırlığ ortalamas $75.36 \pm 7.46 \mathrm{~kg}$ olan $13 \mathrm{~km}(\mathrm{n}=6), 30 \mathrm{~km}(\mathrm{n}=19), 66 \mathrm{~km}(\mathrm{n}=14)$ ve $100 \mathrm{~km}(\mathrm{n}=5)$ mesafelerini koşan 44 kişi gönüllü olarak katıldı. Somatotiplerinin belirlenmesinde Heath \& Carter metodu kullanıldı. Yarış sonuçları organizasyonun web sayfasından alındı. Koşu gruplarını karşılaştırmak için tek yönlü ANOVA; ilişkiyi değerlendirmek için Pearson korelasyonu kullanıldı. Endomorfi $(p=0.000)$ ve mezomorfide $(p=0.035)$ gruplar arası farklılı bulundu. 13 km koşanların endomorf değerleri diğer mesafe koşucuları ile karşılaştııldı̆̆ında anlamlı farklılık gözlendi $(30 \mathrm{~km} \mathrm{p}=0.003 ; 66 \mathrm{~km} \mathrm{p}=$ $0.002 ; 100 \mathrm{~km} \mathrm{p}=0.005) .13 \mathrm{~km}$ koşanların 30,60 ve $100 \mathrm{~km}$ koşanlara göre daha fazla kütleye sahip olduğu, mesafe arttıkça endomorf ve mezomorf değerlerinin düştüğü, uzun mesafe koşan sporcuların ise daha lineer bir fiziksel yapıya sahip olduğu bulundu. Ultra Trail koşularında mesafeye göre somatotip farklılık gösterdiği, performans süresi ve mesafe arttıkça somatotip mezomorfik-ektomorf olduğu söylenebilir.

Anahtar kelimeler: Somatotip, Antropometri, Ultra-trail Koşucuları.

\footnotetext{
* This study was presented as an Oral Presentation at the 18th International Sports Sciences Congress.

† Corresponding Author: Assoc. Prof. İlhan ODABAŞ, E-mail: ilhanodabas@ halic.edu.tr
} 


\section{INTRODUCTION}

In recent years, long-distance running and traditional recreational running activities have become very popular owing to the interest of female and male participants in different age groups from amateur to elite levels. The International Ultrarunner Association (IAU) organizes events including various ultramarathon distances of $50-100 \mathrm{~km}$, and road races are also recognized by the IAU. Therefore, the distance and track level of the races may vary according to organizations and where the event will be held (Costa, Knechtle, Tarnopolsky \& Hoffman, 2019).

Determining the body structure and type of athletes in various sports disciplines has been the subject of numerous studies to date (Berg, Latin \& Coffey, 1998; Campa et al., 2020; Deshpande, Singh, Singh \& Dey, 2020; Gualdi-Russo \& Zaccagni, 2001; Kandel, Baeyens \& Clarys, 2014). Many techniques have been developed in determining body type from past to present, but the anthropometric somatotyping method is one of the most widely used methods (Sheldon, Stevens \& Tucker, 1940). In 1967, Heath \& Carter made an evaluation based on measurements by formulating the somatotype. This method has been widely studied in recent years to examine and reveal variations between different populations, ages and genders (Carter, 1970; Heath \& Carter, 1967). While somatotype in adults is relatively stable, dietary habits and physical activity are among the most common factors that can affect somatotype (Dwiyanti, Hasneli \& Khairunnisa, 2020).

The participant profile of these recreational activities based on long-distance running, where endurance performance is at the forefront, has attracted the attention of sports scientists and has become a multi-faceted research topic (Belli, Meireles, Costa, Ackermann \& Gobatto, 2016; Kłapcińska et al., 2013; Knechtle, Knechtle \& Lepers, 2011). In endurance sports, both physical structure and suitable training programs are important factors affecting performance. Morphological structure, such as body mass, height, skinfold thickness, body fat, length and girth of limbs, body mass index as well as suitable training programs are among the important components of performance in ultra-endurance sports (Alvero-Cruz et al., 2020; Knechtle, 2014). Efficient use of fat stores and the endurance of muscle mass can provide comfortable running on uneven road surfaces in ultramarathon races, and accordingly, leading to cover greater distances (Hoffman, Lebus, Ganong, Casazza \& Van Loan, 2010).

Among the research conducted to date, there are studies that associate individuals who do long distance running (semi-marathon, ultra-marathon or trail races) with physiological and anthropometric characteristics, body composition, running distance, running speed and performance (Festa, Tarperi, Skroce, La Torre \& Schena, 2020; Gómez-Molina et al., 2017; Knechtle \& Nikolaidis, 2018; Lee, Snyder \& Lundstrom, 2020). However, in recent years, there have not been many studies examining the somatotype differentiation and performance relationships of individuals running at different distances in Ultra Trail runs, which are quite popular among long distance runs. Therefore, the purpose of this study is to examine the somatotype differences of men running ultra-trail at different distances, and to reveal the relationship between somatotype and performance. 


\section{METHOD}

\section{Participants}

A total of 44 Turkish male volunteer recreational athletes who participated in $13 \mathrm{~km}(\mathrm{n}=6), 30$ $\mathrm{km}(\mathrm{n}=19), 66 \mathrm{~km}(\mathrm{n}=14)$ and $100 \mathrm{~km}(\mathrm{n}=5)$ races participated in the study. Uludag Premium Ultra Trail ${ }^{\circledR}$ race took place at an altitude of approximately $1726 \mathrm{~m}$ above sea level, at a temperature of $20-25^{\circ} \mathrm{C}$, and in humidity of $49-60 \%$. Descriptive statistics of the participants are shown in Table 1. participants have accepted Uludag Premium Ultra Trail ${ }^{\circledR}$ registration and participation terms and conditions prior to the race. A voluntary consent form was signed by the participants in order to participate in the race. The participants who have been training for more than three years and come from different occupational groups were accepted as an inclusion criteria. Individuals with health problems and those who stated that they consumed ergogenic beverages/foods that were used to improve performance before the race were excluded from the study.

Table 1. Physical characteristics of runners

\begin{tabular}{|c|c|c|c|c|c|c|}
\hline & $\begin{array}{c}\text { Total Group } \\
n=44\end{array}$ & $\begin{array}{c}13 \mathrm{~km} \\
\mathrm{n}=6\end{array}$ & $\begin{array}{l}30 \mathrm{~km} \\
\mathrm{n}=19\end{array}$ & $\begin{array}{l}66 \mathrm{~km} \\
\mathrm{n}=14\end{array}$ & $\begin{array}{c}100 \mathrm{~km} \\
\mathrm{n}=5\end{array}$ & p \\
\hline & $\mathbf{M} \pm \mathbf{S D}$ & $\mathbf{M} \pm \mathbf{S D}$ & $\mathbf{M} \pm \mathbf{S D}$ & $\mathbf{M} \pm \mathbf{S D}$ & $\mathbf{M} \pm \mathbf{S D}$ & \\
\hline Age (year) & $45,63 \pm 9,61$ & $49,5 \pm 12,8$ & $47,05 \pm 8,56$ & $43,85 \pm 8,28$ & $40,6 \pm 8,26$ & 0,321 \\
\hline Height (cm) & $175,84 \pm 6,17$ & $173,3 \pm 5,78$ & $175,10 \pm 7,26$ & $178,64 \pm 5,06$ & $174 \pm 1,64$ & 0,197 \\
\hline Weight (kg) & $75,36 \pm 7,45$ & $79,3 \pm 5,75$ & $74,73 \pm 7,35$ & $76,50 \pm 7,29$ & $69,8 \pm 8,43$ & 0,176 \\
\hline BMI $\left(\mathrm{kg} / \mathrm{m}^{2}\right)$ & $24,38 \pm 2,24$ & $26,43 \pm 2,06$ & $24,38 \pm 2,07$ & $23,67 \pm 2,18$ & $23,96 \pm 2,46$ & 0,063 \\
\hline
\end{tabular}

\section{Anthropometry}

Anthropometric parameters were measured according to the protocol recommended by "The Anthropometric Standardization Reference Manual" (Lohman, Roche \& Martorell, 1988) and were performed by the experts 24 hours before the run. The anthropometric somatotype was calculated from equations according to Carter and Heath (1990). These refer respectively to the endomorphic, mesomorphic, and ectomorphic components of the somatotype (Carter, 2002).

Body weight was measured to the nearest $0.1 \mathrm{~kg}$ in light clothes without footwear using a Tanita BC 730, and a height scale was used in height measurement to the nearest $1 \mathrm{~mm}$. with the subjects standing straight, the head in the Frankfort plane. The body mass index (B.M.I.) was calculated from height and body weight $\left(\mathrm{kg}^{\circ} \mathrm{m}^{-2}\right)$. Biceps and calf girth were measured with a non-plastic tape to the nearest $1 \mathrm{~mm}$. Humerus and femur width were taken using sliding caliper (Lafayette Instrument Company) on the right side of the body. Skinfold thicknesses (to the nearest $0.2 \mathrm{~mm}$ ) were measured at four sites: triceps, subscapular, suprailiac, and medial calf, using a skinfold caliper (Holtain, England). A somatotype is evaluated on the basis of three numbers. The first number indicates the endomorphic and the second one for the mesomorphic while the third one indicates the ectomorphic component. Endomorphy related to the relative fatness or relative thinness of a person, mesomorphy relates to the relative muscular and skeletal development relating to body height, and ectomorphy relates to the length of part of the body (Carter, 2002). 
The anthropometric somatotype was calculated from the following equations according to Carter and Heath (1990):

Endomorphy $=-0.7182+(0.1451 \times X)-(0.00068 \times X 2)+(0.0000014 \times X 3)$, where $X=($ sum of triceps, subscapular, and supraspinal $) \times(170.18 /$ height, $\mathrm{cm})$.

Mesomorphy $=(0.858 \times$ humerus breadth $)+(0.601 \times$ femur breadth $)+(0.188 \times$ corrected arm girth $)+(0.161 \times$ corrected calf girth $)-($ height $\times 0.131)+4.5$, where corrected arm and calf circumferences are the respective limb circumferences minus the triceps and medial calf skinfolds, respectively.

Three equations were used to calculate ectomorphy according to the HWR: If HWR is $\geq 40.7,5$ then ectomorphy $=(0.732 \times$ HWR $)-28.58$; if HWR is less than 40.75 but greater than 38.25 , then ectomorphy $=(0.463 \times \mathrm{HWR})-17.63$; if HWR $\leq 38.25$, then ectomorphy $=0.1$

\section{Running Performance Data}

The race results of the research group were taken from the website of the organization (https://www.uludagultra.com/canli.php?lang=tr).

\section{Research Ethics}

The research was approved by the Halic University Non-Interventional Scientific Research Ethics Committee for human research in accordance with the 2013 Declaration of Helsinki. Participants were informed about the research-related goals, practical details and possible risks and signed a written informed consent form to participate in the study (30.09.2019-141).

\section{Analysis of the Data}

The data of the study were evaluated using IBM SPSS Statistics 24.0 program. The ShapiroWilk test was used to test whether the data fit the normal distribution $(\mathrm{p}<0.05)$. Since the data showed a normal distribution, One-way ANOVA test was used to compare the running groups, and Scheffe post-hoc test was used to determine the significantly different group, and the Pearson correlation test was used for the correlation analysis. The level of significance was set at $\mathrm{p}<0.05$. 


\section{RESULTS}

Somatotypes mean values and average finishing times of the participants and results of ANOVA are presented in Table 2.

Table 2. Mean somatotypes and performance times of runners

\begin{tabular}{|c|c|c|c|c|c|c|c|}
\hline & Total Group & 13 km: A & 30 km: B & $66 \mathrm{~km}: \mathrm{C}$ & 100 km: D & & Significant \\
\hline & $\mathbf{M} \pm \mathbf{S D}$ & $\mathbf{M} \pm \mathbf{S D}$ & $\mathbf{M} \pm \mathbf{S D}$ & $\mathbf{M} \pm \mathbf{S D}$ & $\mathbf{M} \pm \mathbf{S D}$ & & \\
\hline Endomorph & $3,79 \pm 1,20$ & $5,54 \pm 1,38$ & $3,44 \pm 0,95$ & $3,44 \pm 0,95$ & $3,18 \pm 0,54$ & $0,000^{*}$ & $\begin{array}{l}\mathbf{A}>\mathbf{B} \\
\mathbf{A}>\mathbf{C} \\
\mathbf{A}>\mathbf{D}\end{array}$ \\
\hline Mesomorph & $5,19 \pm 1,07$ & $6,19 \pm 1,40$ & $5,24 \pm 0,90$ & $4,98 \pm 0,97$ & $4,43 \pm 0,93$ & $\mathbf{0 , 0 3 5 *}$ & $\mathbf{A}>\mathbf{D}$ \\
\hline Ectomorph & $2,03 \pm 1,01$ & $1,18 \pm 0,74$ & $1,98 \pm 0,98$ & $2,31 \pm 0,95$ & $2,48 \pm 1,19$ & 0,090 & - \\
\hline Time (min) & $476,46 \pm 312,42$ & $93,50 \pm 17,13$ & $275,68 \pm 58,06$ & $728,07 \pm 87,51$ & $994,40 \pm 201,29$ & $0,000 *$ & $\begin{array}{l}\mathbf{A}<\mathbf{B} \\
\mathbf{A}<\mathbf{C} \\
\mathbf{A}<\mathbf{D} \\
\mathbf{B}<\mathbf{C} \\
\mathbf{B}<\mathbf{D} \\
\mathbf{C}<\mathbf{D}\end{array}$ \\
\hline
\end{tabular}

The findings of the study are as follows: at $13 \mathrm{~km}(\mathrm{n}=6)$ one runner is mesomorphic endomorph and five runners are endomorphic mesomorph; at $30 \mathrm{~km}(\mathrm{n}=19)$ one runner is mesomorphic endomorph, eleven runners are endomorphic mesomorph, three runners are balanced mesomorph, one runner is endomorph-mesomorph, two runners are mesomorph-ectomorph and one runner is ectomorphic mesomorph; at $66 \mathrm{~km}(\mathrm{n}=14)$ seven runners are endomorphic mesomorph, four runners are balanced mesomorph, two runners are mesomorphic ectomorph, two runners are mesomorph endomorph; at $100 \mathrm{~km}(\mathrm{n}=5)$ three runners are endomorphic mesomorph and two runners are mesomorphic ectomorph.

According to the results of the ANOVA test, there is a significant difference between the groups in endomorph $(\mathrm{p}=0.000)$ and mesomorph value $(\mathrm{p}=0.035)$. The difference in endomorph parameter was caused by those who ran $13 \mathrm{~km}$ according to the Post-Hoc result, it was also seen that the endomorph values were higher in this group. According to the Scheffe test results, it was observed that there were significant differences $(\mathrm{p}<0.05)$ among the endomorph values of those who ran $13 \mathrm{~km}, 30 \mathrm{~km}(\mathrm{p}=0.003), 66 \mathrm{~km}(\mathrm{p}=0.002)$ and $100 \mathrm{~km}(\mathrm{p}=0.005)$ (Table 2.).

Table 3. Correlation between somatotype and performance

\begin{tabular}{lcccccc}
\hline & \multicolumn{2}{c}{ Endomorph } & \multicolumn{2}{c}{ Mesomorph } & \multicolumn{2}{c}{ Ectomorph } \\
\hline & r & $\mathbf{p}$ & $\mathbf{r}$ & $\mathbf{p}$ & $\mathbf{r}$ & $\mathbf{p}$ \\
\hline Time (min.) &,- 353 & $\mathbf{0 , 0 1 9 *}$ &,- 304 & $\mathbf{0 , 0 4 5 *}$ & 0,219 & 0,153 \\
Running distance $(\mathbf{k m})$ &,- 476 & $\mathbf{0 , 0 0 1 *}$ &,- 411 & $\mathbf{0 , 0 0 6} *$ &, 357 & $\mathbf{0 , 0 1 7 ^ { * }}$ \\
\hline *p<0.05 & & & & & &
\end{tabular}

It was observed that there was a significant negative relationship $(\mathrm{p}<0.05)$ between the time to complete the run and the endomorph $(r=-.353)$ and mesomorph $(r=-.304)$ values of the 
runners. While there was a significant negative relationship between running distance and endomorph $(\mathrm{r}=-.476)$ and mesomorph $(\mathrm{r}=-.411)$, a positive significant relationship $(\mathrm{p}<0.05)$ was found between ectomorph and running distance $(r=.357)$ (Table 3).

\section{DISCUSSION}

In this study, somatotype evaluations of male Ultra Trail runners were determined, and their performance relationships were examined. Somatotypes of all participants were found to be endomorphic mesomorphs $(3.79,5.19,2.03)$. When analyzing the somatotypes according to the distances, the average values were observed to be; $13 \mathrm{~km}$ "endomorphic mesomorph" (5.54, 6.19, 1.19), $30 \mathrm{~km}$ "endomorphic mesomorph" (3.44, 5.24, 1.98), $66 \mathrm{~km}$ "endo mesomorph" (3.44, 4.98, 2.31), $100 \mathrm{~km}$ "endomorphic mesomorph" (3.18, 4.43, 2.48). The results show that the longer the distance, the lower the endomorph and mesomorph values, and the higher the ectomorph values. At the same time, based on the negative relationship between running distance and endomorph and mesomorph values, it can be concluded that those who run $66 \mathrm{~km}$ and $100 \mathrm{~km}$ have a thinner body structure.

It has been reported that long-distance-running male athletes have low fat ratios, thin body structure and ectomorphic features (Tanda \& Knechtle, 2013; Vernillo et al., 2013) and that body weight, height, skinfold thickness, body fat percentage and body mass index have a significant effect on running performance (Knechtle, Wirth, Knechtle, Zimmermann \& Kohler, 2009; Salinero et al., 2016). In the study conducted to determine the body composition and somatotype of young elite $10 \mathrm{~km}$ racing walking athletes; males (2.34 \pm 0.89 endomorph; 3.33 \pm 0.92 mesomorph; $3.39 \pm 0.66$ ectomorph) were found to be mesomorphy-ectomorphy (Gamboa, Espinoza-Navarro, Brito-Hernández, Gómez-Bruton \& Lizana, 2018). In the study of 13-17 age group Turkish male middle-long distance runners $(n=116) 1.85 \pm 0.49$ endomorph; $4.27 \pm 0.93$ mesomorph; $3.41 \pm 1.03$ ectomorph were found (Bayraktar et al., 2010). In another study showing the relationship between the somatotypes and body composition with athletic performance of $20 \mathrm{~km}$ Pan-American elite male walkers, it was found that the somatotype of the best performing athletes was 2.5-3.8-2.9 while it was 2-2.8-4.1 for the lowest performing athletes. It was stated that ectomorphic feature and height are morphological features that can determine the athletic performance (Espinoza-Navarro, Lizana, Gómez-Bruton, Brito-Hernández \& Lagos-Olivos, 2019).

In a study of the somatotypes of South Australian male long-distance runners; 2.0, 4.7, 3.4 was detected as ectomorphic mesomorph (Withers, Craig \& Norton, 1986). In a 2018 research studying the effect of physiological and anthropometric properties of ultra-mountain marathon on performance; somatotype values were found to be $3.1 \pm 0.8$ endomorph, $4.4 \pm 1.1$ mesomorph, and $2.9 \pm 1.2$ ectomorph. As a result of the study, it was concluded that the endomorph structure and fat percentage factors affect the success of the athletes (Rogers, 2018). In our study, it was also observed that endomorph and mesomorph values decreased as the distance increased (11 runners for $30 \mathrm{~km}$, seven for $66 \mathrm{~km}$ and three for $100 \mathrm{~km}$ ).

In another study comparing the anthropometric characteristics and cardiorespiratory capacities of male and female mountain runners; males $(n=32)$ were determined as endomorph $3.17 \pm$ 1.14 , mesomorph as $4.81 \pm 1.29$, ectomorph as $2.19 \pm 1.14$, and the somatotype of male runners 
was determined to be endomorphic mesomorph (Tavera-Melo et al., 2020). In 2002, Carter has reported that marathon runners had the lowest endomorphic levels among others for the distances of 800-1500m and 5000-10,000m (Carter, 2002).

In the study where the resting metabolic rate, somatotype and body composition of ultra-trail and trail running athletes were evaluated, the mean somatotype values of trail runners (19 participants) were found to be (2.4-5.3-2.1) endomorphic mesomorph and Ultra Trail runners (13 participants) were defined as balanced mesomorph. Although there was no significant difference when the body composition values of the two groups were compared, trail runners' total fat percentage and eight skinfold thicknesses were higher than ultra-trail runners (Amorim, Costa, Vardasca \& Pontinha, 2016). Accordingly, in our work, the somatotype mean values of all participants are $(3.79 \pm 1.21 ; 5.24 \pm 1.06 ; 2.04 \pm 1.01)$, and it is similar to the literature with the runners having endomorphic mesomorph features.

As a result of the study conducted by Belli et al., it has been reported that ultramarathoners have an endomorphic mesomorph somatotype, and in addition to this result, fat around waist and lower extremities and abdominal regions can negatively affect the ultramarathon running performance (Belli et al., 2016). Kandel emphasized the importance of endomorph and ectomorph body composition on running performances in 2014 (Kandel et al., 2014). Although Knechtle et al. did not detect a relationship between the anthropometric characteristics and the race times of the athletes participating in the Swiss Jura Marathon (Knechtle, Knechtle \& Rosemann, 2010), positive and/or negative relationships have been found between the race results and the morphological structure of the athletes (Hoffman, 2008; Hoffman et al., 2010; Knechtle, Duff, Welzel \& Kohler, 2009; Zouhal et al., 2009). In the current study, in contrast to Knechtle (2010), a significant negative relationship was found between the athletes' time to complete the run and their endomorph and mesomorph values. Strikingly, it was also found that the longer the running distance, the lighter the athletes are, and their body mass indexes are lower.

\section{CONCLUSION}

As a result, somatotypes of Uludag Premium Ultra Trail ${ }^{\circledR}$ male runners were found to be endomorphic mesomorph. When the comparison was made according to the distances, it was found that there was a significant difference between the endomorph values and running times. It was observed that there was a negative correlation between running distance and endomorph and mesomorph values in the whole group and that the values decreased as the distance increased. There was a significant negative relationship between running performance and ectomorph values of the 30-km-running group. It was found that those who run $13 \mathrm{~km}$ had more mass than those who run 30,60 and $100 \mathrm{~km}$, and their endomorph and mesomorph values were higher. For future, studies, it may be recommended to compare the distance, performance, somatotype, and body composition of men and women participating in ultra-trail races from different geographical regions. 
Conflicts of Interest: The authors declare that they have no conflict of interest.

Author Contributions: Study Design-IO, Data Collection-IO; NS; MA; BKA; MAB, Statistical Analysis-IO; BKA, Manuscript Preparation-IO; NS; MA; BKA; MAB. All authors read and approved the final manuscript.

Research Ethic Ethics Committee: Non-Interventional Scientific Research Ethics Committee of Halic University, Turkey

Date: September 30, 2019 Decision / Protocol number: 141

\section{REFERENCES}

Alvero-Cruz, J. R., Carnero, E. A., García, M. A. G., Alacid, F., Correas-Gómez, L., Rosemann, T., Nikolaidis, P. T. \& Knechtle, B. (2020). Predictive performance models in long-distance runners: A narrative review. International Journal of Environmental Research and Public Health, 17(21), 8289. https://doi.org/10.3390/ijerph17218289

Amorim, S., Costa, R., Vardasca, R. \& Pontinha, M. (2016). Resting metabolic rate, somatotype and body composition of trail running athletes. The International Journal of Sports Physiology and Performance, 11, 1-6.

Bayraktar, I., Deliceoglu, G., Tekelioglu, A., Hazır, M., Kabak, B. \& Ufuk, P. (2010). Erkek adelosan atletlerin antropometrik profil normları. Spor Hekimliği Dergisi, 45, 83-90.

Belli, T., Meireles, C. L. D. S., Costa, M. D. O., Ackermann, M. A. \& Gobatto, C. A. (2016). Somatotype, body composition and performance in ultramarathon. Revista Brasileira de Cineantropometria \& Desempenho Humano, 18, 127-135. https://doi.org/10.5007/1980-0037.2016v18n2p127

Berg, K., Latin, R. W. \& Coffey, C. H. (1998). Relationship of somatotype and physical characteristics to distance running performance in middle age runners. The Journal of Sports Medicine and Physical Fitness, 38(3), 253-257.

Campa, F., Bongiovanni, T., Matias, C. N., Genovesi, F., Trecroci, A., Rossi, A. \& Toselli, S. (2020). A New Strategy to Integrate Heath-Carter Somatotype Assessment with Bioelectrical Impedance Analysis in Elite Soccer Players. Sports, 8(11), 142, 1-10. https://doi.org/10.3390/sports8110142

Carter, J. E. L. (1970). The somatotypes of athletes - a review. Human Biology, 42(4), 535-569.

Carter, J. E. L. \& Heath, B. H. (1990). Somatotyping: development and applications (Vol. 5). Cambridge university press.

Carter, J. E. L. (2002). The Heath-Carter Anthropometric Somatotype. Instruction Manual. Surrey TeP and ROSSCRAFT.

Costa, R. J., Knechtle, B., Tarnopolsky, M. \& Hoffman, M. D. (2019). Nutrition for ultramarathon running: Trail, track, and road. International Journal of Sport Nutrition and Exercise Metabolism, 29(2), 130-140. https://doi.org/10.1123/ijsnem.2018-0255.

Deshpande, N., Singh, G., Singh, J. \& Dey, S. (2020). A Study on national male throwers of different categoriessomatotype perspective. International Journal of Physical Education, Health \& Sports Sciences, 9(1), 77-86.

Dwiyanti, D., Hasneli, H. \& Khairunnisa, K. (2020). The correlation between dietary habits and physical activity with the somatotype of game sports athletes. JUARA, 6(1), 39-41. https://doi.org/10.33222/juara.v6i1.1004 
Odabaş, İ., Suna, N., Aydın, M., Kıstak Altan, B. \& Başar, M.A. (2021). Somatotype role and performance in ultra trail runners. Journal of Sport Sciences Researches, 6(2), 269-278.

Espinoza-Navarro, O., Lagos-Olivos, C., Gómez-Bruton, A., Lizana, P. A. \& Brito-Hernández, L. (2019). Anthropometric characteristics, body composition and somatotype of elite pan-american race walking 20K. International Journal of Morphology, 37(4), 1220-25. http://dx.doi.org/10.4067/S071795022019000401220

Festa, L., Tarperi, C., Skroce, K., La Torre, A. \& Schena, F. (2020). Effects of different training intensity distribution in recreational runners. Frontiers in Sports and Active Living, 1(70), 1-7. https://doi.org/10.3389/fspor.2019.00070

Gamboa, J. D., Espinoza-Navarro, O., Hernández, L. B., Gómez-Bruton, A. \& Lizana, P. A. (2018). Body composition and somatotype of elite 10 kilometers race walking athletes. Interciencia, 43(4), 289-294.

Gómez-Molina, J., Ogueta-Alday, A., Camara, J., Stickley, C., Rodríguez-Marroyo, J. A. \& García-López, J. (2017). Predictive variables of half-marathon performance for male runners. Journal of Sports Science \& Medicine, 16(2), 187-94.

Gualdi-Russo, E. \& Zaccagni, L. (2001). Somatotype, role and performance in elite volleyball players. Journal of Sports Medicine and Physical Fitness, 41(2), 256-262.

Heath, B. H. \& Carter, J. E. L. (1967). A modified somatotype method. American Journal of Physical Anthropology, 27(1), 57-74. https://doi.org/10.1002/ajpa.1330270108

Hoffman, M. D., Lebus, D. K., Ganong, A. C., Casazza, G. A. \& Loan, M. V. (2010). Body composition of 161 $\mathrm{km} \quad$ ultramarathoners. International Journal of Sports Medicine, 31(2),106-109. https://doi.org/10.1055/s-0029-1241863

Hoffman, M. D. (2008). Anthropometric characteristics of ultramarathoners. International Journal of Sports Medicine, 29(10), 808-811. https://doi.org/10.1055/s-2008-1038434

Kandel, M., Baeyens, J. P. \& Clarys, P. (2014). Somatotype, training and performance in Ironman athletes. European Journal of Sport 301-308. https://doi.org/10.1080/17461391.2013.813971

Kłapcińska, B., Waśkiewicz, Z., Chrapusta, S. J., Sadowska-Krępa, E., Czuba, M. \& Langfort, J. (2013). Metabolic responses to a 48-h ultra-marathon run in middle-aged male amateur runners. European Journal of Applied Physiology, 113(11), 2781-2793. https://doi.org/10.1007/s00421-013-2714-8

Knechtle, B. (2014). Relationship of anthropometric and training characteristics with race performance in endurance and ultra-endurance athletes. Asian Journal of Sports Medicine, 5(2), 73-90

Knechtle, B. \& Nikolaidis, P. T. (2018). Physiology and pathophysiology in ultra-marathon running. Frontiers in Physiology, 9(634)-1-33. https://doi.org/10.3389/fphys.2018.00634

Knechtle, B., Duff, B., Welzel, U. \& Kohler, G. (2009). Body mass and circumference of upper arm are associated with race performance in ultraendurance runners in a multistage race-the Isarrun 2006. Research Quarterly for Exercise and Sport, 80(2),262-268. https://doi.org/10.1080/02701367.2009.10599561

Knechtle, B., Knechtle, P. \& Lepers, R. (2011). Participation and performance trends in ultra-triathlons from 1985 to 2009. Scandinavian Journal of Medicine \& Science in Sports, 21(6), e82-e90. https://doi.org/10.1111/j.1600-0838.2010.01160.x

Knechtle, B., Knechtle, P. \& Rosemann, T. (2010). Race performance in male mountain ultra-marathoners: anthropometry or training?. Perceptual and Motor Skills, 110(3), 721-735. https://doi.org/10.2466/PMS.110.3.721-735

Knechtle, B., Wirth, A., Knechtle, P., Zimmermann, K. \& Kohler, G. (2009). Personal best marathon performance is associated with performance in a 24-h run and not anthropometry or training volume. British Journal of Sports Medicine, 43(11), 836-839. http://dx.doi.org/10.1136/bjsm.2007.045716.

Lee, E. J., Snyder, E. M. \& Lundstrom, C. J. (2020). Predictors of long-distance race performance in master runners. Journal of Human Sport and Exercise, 15(2),355-366. https://doi.org/10.14198/jhse.2020.152.10 
Odabaş, İ., Suna, N., Aydın, M., Kıstak Altan, B. \& Başar, M.A. (2021). Somatotype role and performance in ultra trail runners. Journal of Sport Sciences Researches, 6(2), 269-278.

Lohman, T. G., Roche, A. F. \& Martorell, R. (1988). Anthropometric standardization reference manual. Champaign, IL: Human kinetics books.

Rogers, M. J. (2018). Physiological and anthropometric predictors of mountain ultra marathon performance. Doctoral dissertation, Science: Department of Biomedical Physiology and Kinesiology.

Salinero, J. J., Soriano, M. L., Lara, B., Gallo-Salazar, C., Areces, F., Ruiz-Vicente, D., Abián-Vicén J, GonzálezMillán, C. \& Del Coso, J. (2016). Predicting race time in male amateur marathon runners. The Journal of Sports Medicine and Physical Fitness, 57(9), 1169-1177. https://doi.org/10.23736/s00224707.16.06503-8

Sheldon, W. H., Stevens, S. S. \& Tucker, W. B. (1940). The varieties of human physique. New York: Harper and Brothers Publishers.

Tanda, G. \& Knechtle, B. (2013). Marathon performance in relation to body fat percentage and training indices in recreational male runners. Open Access Journal of Sports Medicine, 4, 141-149. https://doi.org/10.2147/OAJSM.S44945

Tavera-Melo, J., Niño, O., Montoya, G., Castro, Y., Garzón, M., Quiroga, N., Castillo, D. \& Yanci, J. (2020). Anthropometric characteristics and cardiorespiratory capacity of male and female trail runners. Archivos de Medicina del Deporte, 37(5),310-317.

Vernillo, G., Schena, F., Berardelli, C., Rosa, G., Galvani, C., Maggioni, M., Agnello, L. \& La Torre, A. (2013). Anthropometric characteristics of top-class Kenyan marathon runners. Journal of Sports Medicine and Physical Fitness, 53(4), 403-408.

Withers, R. T., Craig, N. P. \& Norton, K. I. (1986). Somatotypes of South Australian male athletes. Human Biology, 58(3), 337-356.

Zouhal, H., Groussard, C., Vincent, S., Jacob, C., Abderrahman, A. B., Delamarche, P. \& Gratas-Delamarche, A. (2009). Athletic performance and weight changes during the "Marathon of Sands" in athletes well-trained in endurance. International Journal of Sports Medicine, 30(07), 516-521. https://doi.org/10.1055/s0029-1202350

Except where otherwise noted, this paper is licensed under a Creative Commons Attribution 4.0 International license. 